\title{
The Impact of Soil and Water Conservation Program on the Income and Productivity of Farm Households in Adama District, Ethiopia
}

\author{
Yitayal Abebe* and Adam Bekele
}

\author{
Ethiopian Institute of Agricultural Research (EIAR), Melkassa Agricultural Research Center,
} Post Box No: 436, Adama, Ethiopia

\begin{tabular}{|c|c|}
\hline \multirow{14}{*}{$\begin{array}{l}\text { ADStract } \\
\text { Land degradation due to soil erosion and nutrient depletion is one of the main problems } \\
\text { constraining the development of the agricultural sector in Ethiopia. As part of intervention } \\
\text { activities a number of soil and water conservation (SWC) practices have been promoted to } \\
\text { smallholder farmers living in highly degraded and drought prone areas of the country. This } \\
\text { study was conducted to assess the impact of SWC intervention on the livelihood of smallholder } \\
\text { farm households in terms household income and productivity. To meet this objective primary } \\
\text { data was gathered in } 2012 \text { from } 101 \text { SWC program participants and } 115 \text { non-participants that } \\
\text { were randomly selected from } 3 \text { intervention area and } 3 \text { counterfactual villages respectively. } \\
\text { Descriptive and inferential statistics and propensity score matching (PSM) models were used to } \\
\text { address the stated objectives. Results of the descriptive statistics showed that before matching } \\
\text { there was statistically significant difference between program participants and their } \\
\text { counterfactual households in terms of sex and age of household head, family size and farm } \\
\text { size generally in favor of program participants. Results of the PSM model revealed that SWC } \\
\text { intervention did not result in significant difference between program participant and non- } \\
\text { participant households in terms of total crop and household income, and crop yield. However it } \\
\text { was to be noted that there were positive trends which all together should guide SWC policy } \\
\text { makers to identify important factors influencing the contribution of such a program and } \\
\text { reconsider the design and implementation of the interventions }\end{array}$} & Article Information \\
\hline & Article History: \\
\hline & Received : 19-05-2014 \\
\hline & Revised : $20-08-2014$ \\
\hline & Accepted : 04-09-2014 \\
\hline & Keywords: \\
\hline & Soil and water \\
\hline & Conservation practices \\
\hline & Impact \\
\hline & Oromia region \\
\hline & ${ }^{*}$ Corresponding Author: \\
\hline & Yitayal Abebe \\
\hline & E-mail: \\
\hline & \\
\hline & \\
\hline
\end{tabular}

\section{INTRODUCTION}

Land degradation, due to soil and nutrient loos, is one of the main problems constraining the development of agricultural sectorin Ethiopia (Kirubel and Gebreyesus, 2011). The country loses 30,000 hectares of soil or one billion tons of top soil, 30 kilograms of nitrogen, and 15-20 kilograms of phosphorous per hectare annually from soil erosion. Serious soil degradation has led to a decline in crop yields and reduced the effectiveness of fertilizer use in raising farm productivity (World Bank, 2007). The problem is particularly severe on cultivated marginal and sloping land because such areas are generally susceptible to soil erosion (Million and Belay, 2007).

Recognizing the threat of land degradation, the government of Ethiopia has made several Natural Resource Management (NRM) interventions through productive safety net and food for work programs since mid-1970s and 80s (Aklilu, 2006, Shiferaw and Holden, 1998). As a result a range of conservation practices, which include stone terraces, stone bunds, area closures, and other soil and water conservation technologies have been introduced into individual and communal lands at massive scales.

However, preliminary observation of the intervention areas shows that these efforts have had limited success in addressing the problem. Several studies elsewhere point out that farmers adopt SWC technologies at lower rate and more often they dis-adopt them (Aklilu and de Graaff, 2007).

The positive effects of soil and water conservation (SWC) may occur through time and adoption of SWC agricultural technologies depends on the ability of the technologies to improveagricultural land productivity and income, and risk decisions facing individual households both in short and long term.

While there is a bulk of information regarding the adoption of SWC technologies little information is documented on the impact of the various long-term SWC measures implemented in the country in general, and in the study area in particular. The assessment of the effectiveness of these technologies that are alleged to enhance farm productivity is very important in order to evaluate their performance in reducing land degradation.

Assessing the impact of past efforts and proper understanding of the improvement in the livelihood of smallholder farmers' is essential to draw lessons and as a baseline information for future studies. It can also assist the setting of agricultural research and development priorities. 
Yitayal Abebe and Adam Bekele

Therefore this study will focus on evaluating the impact of in-situ SWC policy intervention and institutional arrangement on the improvement of the livelihood (measured in terms of crop productivity and income) of smallholder farm households considering Adama District, Oromia National Regional State, where the problem of land degradation and a number of intervention measures has taken place for more than 10 years.

\section{MATERIAL AND METHODS}

\section{The Study Location}

Adama, the study area, is one of the 180 districts in Oromia Regional state of Ethiopia. Adama district is bordered on the south by Arsi Zone, on the southwest by Koka Reservior, on the west by Lome, on the north by the Afar Region, and on the east by Boset district. The altitude of this district ranges from 1500 to 2300 meters above sea level and it receives average annual rainfall of $700 \mathrm{~mm}$. it is estimated that $30 \%$ land is arable, $6.5 \%$ pasture, $5.2 \%$ forest, and the remaining $58.3 \%$ is considered swampy, degraded or otherwise unusable.

With an estimated area of 871.18 square kilometers, Adama has an estimated population density of 207.4 people per square kilometer, which is greater than the Zone average of 189.6. The average farmland size per household was 2.5 hectares. Cereals and pulses accounted for $96 \%$ of the cultivated land (CSA, 2012).

\section{Data Type and Source}

The study utilizes primary and secondary data that were collected from sample farm households and from reports of Bureaus of agriculture and published and unpublished sources, respectively. The primary data included detailed information regarding demographic characteristics of farm households, resource endowments, agricultural production, income, access to extension and credit services. Secondary data focused on SWC policy interventions and relevant studies. A pretested structured questionnaire was used to collect primary data at household level. The questionnaire was administered to sample farmers in their native languages (i.e., Afan Oromo and Amharic) by trained enumerators during March to April 2012. Close field supervision of the process of data collection and on spot checking and correction of major data recording was made by the investigators.

\section{Sampling Design}

Two-stage sampling technique was applied to select sample households for this study. In the first stage, SWC technology adopting villages were identified with district level experts of bureau of agriculture. Then three intervention villages were selected randomly and three counterfactual villages were selected based on similarity with the randomly selected villages in terms of land degradation, cropping system, soil type and topography using ranking method. In the second stage, a total of 216 households were selected from each village randomly. The sampling size in each village was determined using probability proportional to size.

\section{Methods of Data Analysis}

Basic statistics and econometric methods were used to analyze the empirical data and SPSS version 20 and STATA version 12 were used for this purpose. Descriptive and inferential statistics were used to describe sampled households and draw relevant conclusions about them in
Sci. Technol. Arts Res. J., July-Sep 2014, 3(3): 198-203

terms of the deferent demographic, economic and institutional characteristicsand the SWC technologies that have been made available to farmers.

A number of econometric methods have been used elsewhere to study impact of programs (Pender and Gebremedhin, 2006) and as each of them had their own limitations there was no superior method. However, the propensity score matching (PSM) has become a popular approach to estimate causal treatment effects and is being increasingly applied in policy program evaluations (Heinrich et al., 2010) mainly because it is based on comparable observations which reduces the selection problem when there are two categories of response. This study used PSM to analyze the impact of SWC practices on small holder farmers' livelihood defined by crop productivity and income using pre-intervention cross sectional data.

\section{The PSM framework}

Considering the dichotomous nature of theresponse variable, participation and non-participation in SWC taking 0-1 value, and the simplicity of the model for interpretation of results the logit model (Gujarati and Porter, 2009) was chosen to estimate propensity scores using a composite of pre-intervention characteristics of the sampled households (Rosenbaum and Robin, 1983).

In estimating the logit model, the dependent variable was SWCprogram participation status, which takes the value of 1 if a household participated in the SWC program and 0 otherwise.

The logit model, following Gujarati and Porter (2009,) was constructed over probabilities. Accordingly, given the probability of being in the SWC program $\left(\mathrm{P}_{\mathrm{i}}\right)$

$$
\mathrm{P}_{\mathrm{i}}=\frac{\mathrm{e}^{\mathrm{z}_{\mathrm{i}}}}{1+\mathrm{e}^{\mathrm{z}_{\mathrm{i}}}}(1)
$$

and, the probability that a household belongs to nonprogram (1-Pi)

$$
1-P_{i}=\frac{1}{1+e^{z_{i}}}(2)
$$

the odds ratio $\left(\frac{P_{i}}{1-P_{\mathrm{i}}}\right)$ is defined as:

$$
\frac{P_{i}}{1-P_{\mathrm{i}}}=\frac{1+\mathrm{e}^{\mathrm{z}_{\mathrm{i}}}}{1+\mathrm{e}-\mathrm{z}_{\mathrm{i}}}=e^{z_{i}}(3)
$$

and, L, the logit model was modelled by the following relationships;

$$
\mathrm{L}_{i}=\ln \left(\frac{P_{i}}{1-P_{i}}\right)=Z_{i}=\beta_{1}+\beta_{2} X_{i}+U_{i}(4)
$$

Where, $P_{i}$ is the probability of participation, e $=2.71828, i=1,2,3,---, n, \beta_{1}=$ intercept, $\beta_{2}=$ regression coefficients to be estimated, $X_{i}=$ pre-SWC program intervention characteristics and $U_{i}=$ a disturbance term. Subsequently, inference about the impact SWC program on the outcome parameters of an individual involves speculation about how this individual would have performed had (s) he not received SWC program components. Therefore, the standard framework in evaluation analysis to formalize this problem; i.e., the potential outcome approach or Roy-Rubin model (Roy, 1951; Rubin, 1974) has been used. The potential outcomes were then defined as $\mathrm{Yi}(\mathrm{Di})$ for each individual $\mathrm{i}$, where $\mathrm{Yi}=$ outcome variable, $\mathrm{i}=1 \ldots \mathrm{N}$ and $\mathrm{N}$ denotes the 
Yitayal Abebe and Adam Bekele

total population, whereas, the treatment effect (TEi) for an individual i were calculated using

$$
\mathrm{TEi}=\mathrm{Yi}(1)-\mathrm{Yi}(0)(5)
$$

From equation (5), two parameters (ATE and ATT) are most frequently estimated in literature. The first one is the population average treatment effect (ATE), which is simply the difference of the expected outcomes after participation and nonparticipation given by:

$$
\mathrm{TATE}=\mathrm{E}(\mathrm{T})=\mathrm{E}[\mathrm{Y}(1)-\mathrm{Y}(0)](6)
$$

Secondly, as stated in Rosenbaum and Rubin (1983) if the exposure to treatment is random within cells defined by $X$, it is also random within cells defined by the values of the mono-dimensional variable $p(X)$ given by the following relationships.

$$
p(X)=\operatorname{Pr}\{D=1 \mid X\}=E\{D \mid X\},
$$

where $D=\{0,1\}$ is the indicator of exposure to treatment (variable for treatment group selection) and $X$ is the multidimensional vector of pre-treatment characteristics. Propensity scores therefore describe the likelihood that a population member would have been selected into the treatment group based on a set of model covariates, given they were eligible.

As a result, given a population of units denoted by $i$, if the propensity score $p(X i)$ is known, the Average effect of Treatment on the Treated (ATT) was estimated as follows:
Sci. Technol. Arts Res. J., July-Sep 2014, 3(3): 198-203

$$
\begin{gathered}
A T T \equiv E\{Y 1 i-Y 0 i \mid D i=1\} \\
=E\{E\{Y 1 i-Y 0 i \mid D i=1, p(X i)\}\} \\
=E\{E\{Y 1 i \mid D i=1, p(X i)\}-E\{Y 0 i \mid D i=0, p(X i)\} \mid D i=1\}
\end{gathered}
$$

Where, the outer expectation is over the distribution of $(p(X i) \mid D i=1)$ and $Y 1 i$ and $Y 0 i$ are the potential outcomes in the treatment(i.e. SWC program participation) and nontreatment (non-participation) groups respectively.

\section{RESULTS AND DISCUSSION}

\section{Descriptive and Inferential Analysis}

Results of the descriptive and inferential analyses show that there were statistically significant differences between SWC program households and their counterparts before intervention with regard to demographic and economic characteristics. The groups differ in terms of sex, age, family size, and farm size (Table 1). Therefore, it can be inferred that, compared to their counterfactuals, SWC program participants had relatively better position considering these characteristics before SWC program intervention, except age. There was no statistically significant difference between the two groups in terms of

\begin{tabular}{|c|c|c|c|c|c|c|c|}
\hline \multirow{2}{*}{$\begin{array}{l}\text { Pre-intervention } \\
\text { Variables }\end{array}$} & \multicolumn{2}{|c|}{$\begin{array}{l}\text { Total Sample } \\
(n=216)\end{array}$} & \multicolumn{2}{|c|}{$\begin{array}{c}\text { Program } \\
(n=101)\end{array}$} & \multicolumn{2}{|c|}{$\begin{array}{c}\text { Non-program } \\
(n=115)\end{array}$} & \multirow[t]{2}{*}{$\chi^{2} / \mathrm{t}$-value } \\
\hline & Mean & STD & Mean & STD & Mean & STD & \\
\hline Sex (\% female) & 16.8 & - & 8.7 & - & 12.5 & - & $03.25^{\star \star \star}$ \\
\hline Education (\% illiterate) & 31.7 & - & 31.3 & - & 31.5 & - & 00.04 \\
\hline Age household head & 42.89 & 12.13 & 44.46 & 11.32 & 41.51 & 12.69 & $01.79^{* * *}$ \\
\hline Farming experience & 27.17 & 12.23 & 28.58 & 11.76 & 25.93 & 12.55 & 01.60 \\
\hline Family size & 6.49 & 2.84 & 7.24 & 3.04 & 5.83 & 2.48 & $03.76^{*}$ \\
\hline Dependency ratio & 1.0 & 0.84 & 0.97 & 0.77 & 1.02 & 0.90 & -00.50 \\
\hline Farm size & 1.90 & 1.24 & 2.07 & 1.13 & 1.75 & 1.32 & $01.91^{\star \star *}$ \\
\hline Tropical livestock unit & 4.59 & 3.18 & 4.69 & 3.19 & 4.52 & 3.18 & 00.40 \\
\hline Slope (\% high) & 27.78 & - & 53.24 & - & 46.76 & - & $13.22^{* * *}$ \\
\hline DSPLOT & 21.12 & 14.17 & 22.46 & 17.05 & 19.96 & 10.99 & 01.30 \\
\hline
\end{tabular}
education status, farming experience, age dependency ratio, livestock size and distance to farm plots. Generally male and literate households dominate in the sampled households.

Table 1: Demographic and economic characteristics of sample households

Different types of physical soil and water conservation measures were introduced to the study area with the objectives of conserving, developing and rehabilitating degraded agricultural lands and increasing food security through increased productivity.

Table 2: Length of soil and water conservation structures on farm in meter/number)

\begin{tabular}{lccc}
\hline \multicolumn{1}{c}{ SWC technologies } & $\mathbf{n}$ & Mean & STD \\
\hline FANYA JUU & 97 & 188.27 & 257.00 \\
SOIL BUND & 67 & 183.60 & 220.27 \\
CUT OFF DRAIN & 86 & 115.90 & 137.55 \\
STONE BUND & 69 & 96.70 & 119.02 \\
TERRACE & 87 & 88.39 & 155.68 \\
FARM FORESTRY (in number) & 28 & 149.32 & 248.66 \\
\hline
\end{tabular}

The soil and water conservation measures introduced to the area include soil bund, terrace, cut off drain, stone bund and fanyajuu (terrace formed by digging holes to form uphill embankment) and farm forestry. Table 2 indicates that most of the SWC program farmers adopted fanyajuu on $(n=97)$, terraces 87$)$ and cut of drain $(n=86)$ on their farms. In terms of intensity of adoption, on average, fanyajuu (mean $=188.27 \mathrm{~m}$ ), soil bund (mean $=183.60 \mathrm{~m}$ ) and cut off drain (mean $=115.9 \mathrm{~m}$ ) take the lead in that order. However, the large standard deviation shows existence of variability among program participants in terms of intensity of adoption of SWC technologies. Terracing was the least adopted of all technologies availed to the program households (mean=88.39) .

\section{Household income and crop productivity}

Table 3 shows the mean difference in outcome variables before matching. Program and non-program households did not have statistically significant difference in terms of all outcome variables considered i.e. gross and net crop income, and gross and net household income and crop productivity (ton/ha) defined in terms of tefequivalent yield. However, this descriptive result cannot tell us whether the observed difference is exclusively because of the program; as comparisons are not yet restricted to households who have similar characteristics. Hence, further analyses were performed using propensity score matching techniques to address this issue. 
Table 3: Comparison of program participants and their counterfactuals in terms of household income and crop productivity

\begin{tabular}{lccccccc}
\hline \multirow{2}{*}{\multicolumn{1}{c}{ Income type }} & \multicolumn{2}{c}{ Total Sample } & \multicolumn{2}{c}{ Program } & \multicolumn{2}{c}{ Non- Program } & \multirow{2}{*}{ t-value } \\
\cline { 2 - 7 } & Mean & STD & Mean & STD & Mean & STD & \\
\hline Gross crop income & 34331.1 & 34331.1 & 33903 & 29941.7 & 33808.4 & 35321.8 & 0.02 \\
Gross household income & 37954.1 & 37954.1 & 38311.7 & 30858.4 & 37640 & 37246.9 & 0.14 \\
Net crop income & 27240.6 & 29396.1 & 26847.1 & 26676.1 & 27586.3 & 31705.5 & -0.18 \\
Net household income & 31342.1 & 30978.4 & 31255.7 & 27656.4 & 31417.9 & 33748.1 & -0.04 \\
Productivity in Tef-equivalent (TON) & 4.89 & 28.3 & 4.91 & 27.6 & 4.88 & 29.0 & 0.08 \\
\hline
\end{tabular}

\section{Econometric Model Outputs}

\section{Estimation of propensity score}

Before and after estimation of the propensity score and the logistic model appropriate diagnostic measures were used on the data and the hypothesized variables. Accordingly the tests for outlying observations, mullticollinearity, heteroscedasticity and model specification, goodness of fit and omitted variables were done. Outlying observations with extreme influence (residual value of $>2.5$ ) were removed from analyses. To this effect 18 observations were discarded. Results of multicollinearity test using variance inflation factor and condition index showed that there was no serious problem of multicollinearity detected. Similarly, the test for the presence of heteroscedasticity using Breusch-Pagan test showed that there was no heteroscedasticity problem at $<5 \%$ probability level $(P=0.67)$ and a further comparison of the standard errors showed that there was no difference between the two cases. Hence other methods were not needed to correct for the problem of heteroscedasticity. Results of post estimation tests showed that the model performed well. The model in general was significant at $<1 \%$ level of significance showing the appropriateness of the model for estimation. The goodness-of-fit test using Hosmer-Lemeshow did not result in statistically significant values $\left(\chi^{2}=6.85, P=0.55\right)$, suggesting that the model was fit to explain the relationship well. The model was also checked for model specification using link test and results indicated that there was no such a problem $(P=0.66)$.

The first step taken to evaluate impact of SWC program on crop income and crop productivity was estimation of propensity scores based on the selected covariates. Logistic regression model was employed to estimate propensity scores for matching SWC program households with their counterfactuals. The dependent variable in this model was a dummy variable indicating whether a given household has participated in the SWC program taking a value of 1 or 0 otherwise. Therefore, before matching, results of logit estimation showed that SWC program participation status has been significantly influenced by six variables (Table 4). Sex of household head, farming experience, family size, distance to plot, farm size and livestock ownership were found to affect the probability of adopting SWC technology significantly. Sex of household head, farming experience family size, and steepness of slope influenced the probability of SWC participation positively and significantly at $<5 \%$. On the other hand ownership of large farm size and livestock affected participation negatively at $<1 \%$ significance level. The implication could be that farm household participation was more guided by demographic than economics factors (defined by farm size and herd size).

Estimation of logit model was followed by series of activities involving defining region of common support, matching and testing the balance for matching program and non-program households for isolating causal effects of SWC program.

Table 4: Results of logit estimation household program participation

\begin{tabular}{|c|c|c|c|}
\hline Variables & Coef. & Std. Err. & $\mathbf{Z}$ \\
\hline SEX & 1.733 & 0.685 & $2.53^{\star *}$ \\
\hline EDUC & -0.121 & 0.077 & -1.57 \\
\hline FARMEXP & 0.047 & 0.020 & $2.30^{\star *}$ \\
\hline FAMSIZE & 0.101 & 0.082 & $1.23^{\star *}$ \\
\hline DEPRATIO & -0.244 & 0.228 & -1.07 \\
\hline FARMSIZE & -0.778 & 0.251 & $-3.10^{\star \star *}$ \\
\hline TLU & -0.194 & 0.081 & $-2.39^{\star \star *}$ \\
\hline STPSLOP & 3.071 & 0.550 & $5.58^{\star \star}$ \\
\hline DSPLOT & 0.017 & 0.017 & 1.02 \\
\hline cons & 3.983 & 1.561 & 2.55 \\
\hline \multicolumn{4}{|c|}{ Number of obs $=198$} \\
\hline \multicolumn{4}{|c|}{$\mathrm{LRChi}^{2}(9)=36.10$} \\
\hline \multicolumn{4}{|c|}{ Prob $>C h i^{2}=0.000$} \\
\hline \multicolumn{4}{|c|}{ Log likelihood = -90.3145} \\
\hline Pseudo $R^{2}$ & $=0.1241$ & & \\
\hline
\end{tabular}

\section{Defining region of common support}

Identification of common support or overlap condition for program and non-program households was done in order to estimate causal treatment effects (in this case, SWC outcome) since violation of the common support condition is a major source of selection bias (Heckman et al., 1997). We used the estimated propensity scores us to define the common support region and results of data analysis are depicted in Table 5. The estimated propensity scores as shown in the Table vary between 0.144 and 0.937 (mean $=0.538$ ) for program households and between 0.114 and 0.858 (mean $=0.385$ ) for nonprogram households. Therefore our common support region according to Caliendo and Kopeining, (2008) would lie between 0.144 and 0.858 . As a result of this restriction, 8 households (6 program and 2 non-program households) were dropped in estimating the average treatment effect.

Table 5: Distribution of estimated propensity scores

\begin{tabular}{llllll}
\hline Groups & Obs. & Mean & STD & Min & Max \\
\hline $\begin{array}{l}\text { All households } \\
\text { Program }\end{array}$ & 198 & 0.455 & 0.196 & 0.114 & 0.937 \\
$\begin{array}{l}\text { households } \\
\begin{array}{l}\text { Non-program } \\
\text { households }\end{array}\end{array}$ & 108 & 0.538 & 0.201 & 0.144 & 0.937 \\
\hline
\end{tabular}

Figure 1 depicts the distribution of households with respect to estimated propensity scores before and after matching (left and right hand side figures respectively). Before matching, most of the SWC program participants were found in the center and in the right side of the distribution, whereas their counterparts were found in the 
Yitayal Abebe and Adam Bekele

left side of the distribution. Both (SWC and non-SWC) groups show a generally declining density of propensity score from left to right. After imposition of the common support condition both groups had overlapping region

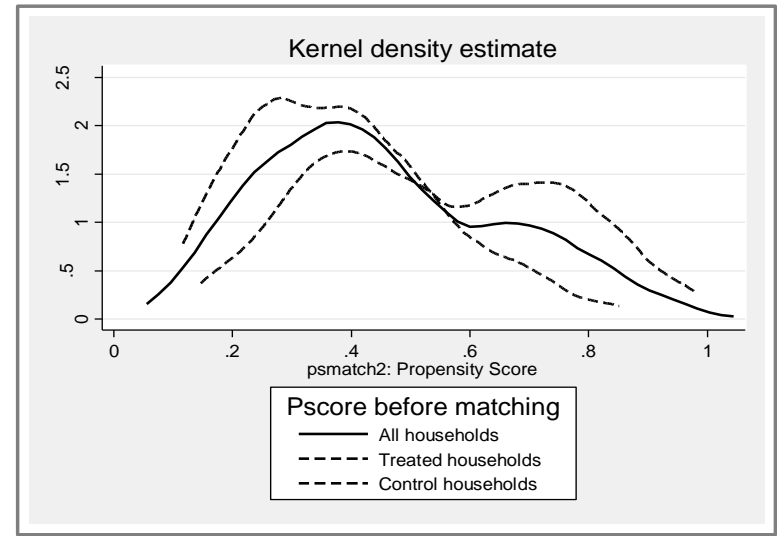

Sci. Technol. Arts Res. J., July-Sep 2014, 3(3): 198-203

though most of the program households had propensity scores concentrated around 0.4 while majority of the nonprogram households have propensity scores concentrated around 0.3 .

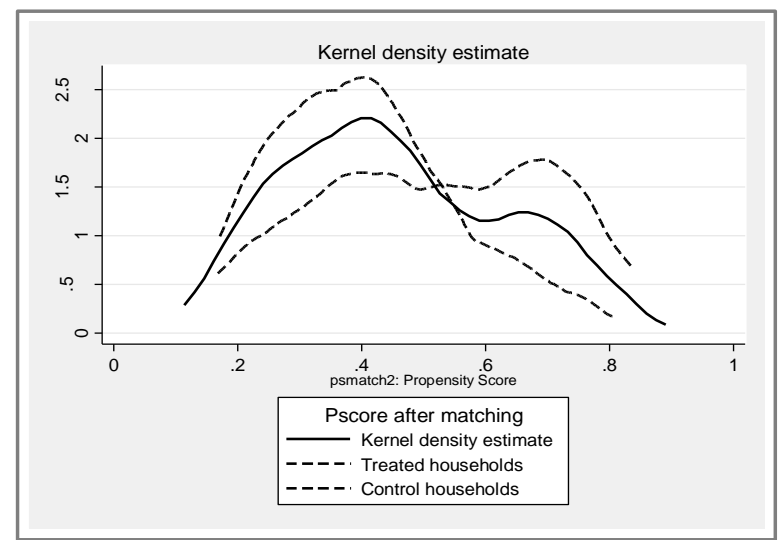

Figure 1: Density of propensity scores of before and after matching

\section{Matching Program and Non-program Households}

Nearest neighbor, Caliper and Kernel matching estimators were used in matching the program and nonprogram households in the already defined common support region. The final choice of a matching estimator was guided by three criteria; namely, the equal mean test (balancing test), pseudo- $R^{2}$ and matched sample size (Caliendo and Kopeining, 2008). In general, a matching estimator which balances all explanatory variables, bears a low pseudo- $R^{2}$ value and also results in large matched sample size is preferable. Therefore, caliper matching with tolerance level of 0.25 was found to be the best matching algorithm for the data we have on 190 matched observations (Table 6).

\section{Testing the Balance of Propensity Score \& Covariates}

The balancing test involves a test of equality of means of covariates; i.e., observations with the same propensity score must have the same distribution of observable (and unobservable) characteristics independently of the treatment status (Becker and Ichino, 2002). The results on Table 7 below show that SWC program and non-program households had no statistically significant difference in terms of all of the covariates after matching, indicating similarities between the two groups.
Table 6: Performance of matching estimators

\begin{tabular}{lccc}
\hline \multirow{2}{*}{$\begin{array}{l}\text { Matching } \\
\text { Estimator }\end{array}$} & \multicolumn{3}{c}{ Performance Criteria } \\
\cline { 2 - 4 } & $\begin{array}{c}\text { Balancing } \\
\text { Test }^{*}\end{array}$ & $\begin{array}{c}\text { Pseudo- } \\
\mathbf{R}^{\mathbf{2}}\end{array}$ & $\begin{array}{c}\text { Matched } \\
\text { Sample Size }\end{array}$ \\
\hline NN & 5 & 0.103 & 190 \\
NN(1) & 6 & 0.098 & 190 \\
NN(2) & 6 & 0.090 & 190 \\
NN(3) & 7 & 0.086 & 190 \\
NN(4) & 7 & 0.083 & 190 \\
NN(5) & & & \\
Caliper & 7 & 0.063 & 190 \\
0.1 & $\mathbf{9}$ & $\mathbf{0 . 0 1 1}$ & $\mathbf{1 9 0}$ \\
$\mathbf{0 . 2 5}$ & 8 & 0.057 & 190 \\
0.5 & & & \\
\hline Kernel & 7 & 0.074 & 190 \\
Band width of 0.1 & 8 & 0.026 & 190 \\
Band width of 0.25 & 9 & 0.013 & 190 \\
Band width of 0.5 & 9.5
\end{tabular}

${ }^{*}$ Number of explanatory variables with no statistically significant mean differences between the matched groups of program and non-program households.

Table 7: Propensity score and covariate balance

\begin{tabular}{lcccccc}
\hline & Before Matching (N=198) & \multicolumn{3}{c}{ After Matching (N=190) } \\
\hline \multicolumn{1}{c}{ Variable } & $\begin{array}{c}\text { Program } \\
\mathbf{( N = 9 0 )}\end{array}$ & $\begin{array}{c}\text { Non-program } \\
\mathbf{( N = 1 0 8 )}\end{array}$ & t-value & $\begin{array}{c}\text { Program } \\
\mathbf{( N = 8 4 )}\end{array}$ & $\begin{array}{c}\text { Non-program } \\
\mathbf{( N = 1 0 6 )}\end{array}$ & t-value \\
\hline SEX & 1.2059 & 1.3627 & $-2.51^{* *}$ & 1.1389 & 1.1107 & 0.26 \\
EDUC & 2.0196 & 1.1667 & $2.66^{*}$ & 2.2917 & 2.5091 & -0.26 \\
FARMEXP & 27.961 & 22.343 & $2.99^{*}$ & 26.278 & 25.623 & -0.21 \\
FAMSIZE & 6.4706 & 6.2157 & 0.74 & 6.4722 & 6.3405 & -0.33 \\
DEPRATIO & 0.94676 & 0.9451 & 0.01 & 1.044 & 1.0465 & 0.07 \\
FARMSIZ & 1.5844 & 1.712 & -1.04 & 1.6139 & 1.6088 & -0.05 \\
TLU & 3.518 & 4.3213 & $-2.15^{* *}$ & 4.028 & 3.9682 & 0.11 \\
STPSLOP & 1.5098 & 1.5098 & 0.00 & 1.6944 & 1.8303 & -0.05 \\
DSPLOT & 21.646 & 17.249 & $2.10^{* *}$ & 21.26 & 20.297 & 0.08 \\
\hline \multicolumn{2}{c}{${ }^{*}$ and ${ }^{* *}$ means significant at the $10 \%$ and 5\% } & probability level respectively.
\end{tabular}

Further test of joint significance of variables revealed that, after matching, the pseudo- $R^{2}$ was fairly low and likelihood ratio tests were in significant (Table 8 ). This supports the hypothesis that both groups have the same distribution in the covariates after matching.
The aforementioned results clearly show that the matching procedure was able to balance the characteristics in the treated (SWC program participants) and the matched comparison groups and provides statistical evidence on the possibility of evaluating the 
Yitayal Abebe and Adam Bekele

effect of SWC program among groups of households that have similar observed characteristics.

Table 8: Chi-square test for joint significance of variables

\begin{tabular}{cccc}
\hline Sample & Pseudo R $^{2}$ & LR chi $^{\mathbf{2}}$ & $\mathbf{p}>\mathbf{c h i}^{\mathbf{2}}$ \\
\hline Unmatched & 0.124 & 36.10 & 0.000 \\
Matched & 0.011 & 2.99 & 0.982 \\
\hline
\end{tabular}

\section{Impacts of SWC program}

In this section, the study provides evidence about the contribution of the SWC program in considering crop
Sci. Technol. Arts Res. J., July-Sep 2014, 3(3): 198-203

productivity and household income. Nominal results of analysis of treatment effects indicate that there was a sign of positive impact on all of the variables considered due to SWC program (Table 9). However, the changes in crop productivity and gross household income could not be statistically justified as there was no statistically significant difference between the two groups in terms of these variables. The possible reason could be that SWC programs are not short-term nature and impacts are to be realized gradually with increased adoption and intensification of activities.

Table 9: ATT for outcome variables of interest

\begin{tabular}{lccccc}
\hline \multicolumn{1}{c}{ Outcome variable } & ATT on Treated & ATT on Control & Difference & S.E. & $\boldsymbol{t}$-value \\
\hline Crop productivity (in tef-equivalent kg/ha) & 46.99 & 44.89 & 2.11 & 6.04 & 0.35 \\
Gross crop income & 27508.7 & 27416.8 & 91.93 & 5220.83 & 0.02 \\
Gross household income & 31869.5 & 30700.7 & 1168.86 & 5628.92 & 0.21 \\
\hline
\end{tabular}

The result obtained agrees with studies by Oudul et al., (2011) who found that adoption of SWC has had no significant impact on technical efficiency of smallholder farmers in Rwanda and the Democratic Republic of Congo. Some other studies have concluded that the impact may even be negative. For instance, Nyangena and kholin (2008) found that plots without SWC had higher yield values per hectare than those with SWC. Also, Menale et al. (2008) made similar conclusion that the value of crop production for plots with bunds was lower than for plots without bunds.

\section{CONCLUSIONS}

The result of the study reveals that, soil and water conservation interventions may not result in significant improvement on crop productive and income and hence there is a need to critically evaluate such a program regularly. Also, it is suggested that, SWC program designers and implementers at all levels, should reevaluate the program design and implementation and promote the positive signs of the program for achieving the desired objective of increased net crop and household income. Further studies may also be appropriate to identify the underlying causes governing the achievement of the program.

\section{REFERENCES}

Aklilu Amsalu and Jande, G. (2007). Determinants of adoption and continued use of stone terraces for soil and water conservation in an Ethiopian highland watershed. Journal of Ecological Economy 61: 294-302.

Aklilu Amsalu. (2006). Caring for the land: Best practices in soil and water conservation in Beressa watershed, highlands of Ethiopia. Thesis Wageningen UR-ISBN: 908504443-X

Becker, S.O., and Ichino, A. (2002). Estimation of average treatment effects based on propensity scores. The Stata Journal 2 (4): 358-377.

Caliendo, M., Kopeinig, S. (2008). Some practical guidance for the implementation of propensity score matching. IZA Discussion Paper No. 1588, University of Cologne.

CSA (Central Statistical Agency of Ethiopia).(2012). Population statistical abstract. Addis Ababa.

Heckman, J., Ichimura, H., Smith,J. and Todd, P. (1998).Characterizing selection bias using experimental data. Econometrica 66(5): 1017-1098.
Heinrich C., Alessandro,M. and Vázquez, G. (2010). A primer for applying propensity score matching. Impact-Evaluation Guidelines Technical Notes No. IDB-TN-161.

Gujarati, D. N. and Porter, D.C. (2009). Basic econometrics (5th Ed.). New York: McGraw-Hill. 553-555pp

Kirubel, M., Gebreyesus, B. (2011). Impact assessment of soil and water conservation measures at Medego watershed in Tigray, northern Ethiopia. Maejo International Journal of Science and Technology 5(3): 312-330.

MenaleKassie, Holden, S., Kohlin, G. and Bluffstone, R. (2008). Economics of soil conservation adoption in HighRainfall areas of the Ethiopian Highlands. EfD DP 08-09.

Million Taddesse and Belay Kassa. (2007). Factors influencing adoption of soil conservation measures in southern Ethiopia: The Case of Gununo Area. Journal of Agriculture and Rural Development in the Tropics and Subtropics 105(1): 49-62

Nyangena W. and Kohlin, G. (2008). Estimating Returns to Soil and Water Conservation Investments: An Application to Crop Yield in Kenya. EfD DP 08-32.

Oudul, J.B., Binam, J.N., Olarinde, L., Diagne, A., Adekunle, A. (2011). Impact of adoption of soil \& water conservation technologies on technical efficiency: Insight from smallholder farmers in Sub-Saharan Africa. Journal of Development and Agricultural Economics 3(14): 655-669.

Pender, J. and Gebremedhin Brhanu. (2006). Land management, crop production and household income in the Highlands of Tigray, Northern Ethiopia: An Econometric Analysis. International Food Policy Research Institute, Washington, DC.

Rosenbaum, P.R. and Rubin, D.B. (1983). The central role of the propensity score in observational studies for causal effects. Biometrika 70(1): 41-55.

Roy, A.D. (1951). Some Thoughts on the Distribution of Earnings. Oxford Economic Papers 3: 135-146.

Rubin, D.B. (1974). Estimating Causal Effects of Treatments in Randomized and Nonrandomized Studies. Journal of Educational Psychology 66: 688-701

World Bank. (2007). Ethiopia: Thematic papers on land degradation on Ethiopia. MOARD and World Bank, Addis Ababa, Ethiopia. 